\title{
Gene Positioning
}

\section{Carmelo Ferrai, Inês Jesus de Castro, Liron Lavitas, Mita Chotalia, and Ana Pombo}

Genome Function Group, MRC Clinical Sciences Centre, Imperial College School of Medicine, Hammersmith Hospital Campus, Du Cane Road, London W12 0NN, United Kingdom

Correspondence: ana.pombo@csc.mrc.ac.uk

Eukaryotic gene expression is an intricate multistep process, regulated within the cell nucleus through the activation or repression of RNA synthesis, processing, cytoplasmic export, and translation into protein. The major regulators of gene expression are chromatin remodeling and transcription machineries that are locally recruited to genes. However, enzymatic activities that act on genes are not ubiquitously distributed throughout the nucleoplasm, but limited to specific and spatially defined foci that promote preferred higher-order chromatin arrangements. The positioning of genes within the nuclear landscape relative to specific functional landmarks plays an important role in gene regulation and disease.

$\mathrm{R}^{\mathrm{e}}$ egulation of gene expression is vital to establishing the metabolic activities in every cell in all organisms, and allows their adaptation to both stress and developmental processes. In humans, more than 20,000 genes and at least an equal number of noncoding transcription units are distributed among the 22 pairs of autosomes and two sex chromosomes. The physical organization of chromosomes within the nucleus occurs in a hierarchical manner. At the most basic level of organization, DNA winds around octamers of histone molecules leading to the formation of nucleosomes and adjacent nucleosomes are linked via DNA. Nucleosome arrays have an inherent propensity to form compacted, filamentous structures with the extent of condensation proposed to have regulatory potential. Condensed nucleosome arrays form fibers with a diameter of approximately $30 \mathrm{~nm}$ (Dorigo et al. 2004), a conformation in which the accessibility of DNA may be restricted. Chromatin condensation can result in masking of regulatory sequences thereby affecting transcription (Cairns 2005). Decondensed, open chromatin is thought to be more accessible to factors necessary for the activation and transcription of genes (Cosma 2002; Sproul et al. 2005), and is also segregated toward the nuclear interior in most cell types (Solovei et al. 2009). Important processes that affect the condensation status of chromatin include the covalent modification of histone tails within nucleosomes and the repositioning of nucleosomes along the DNA fiber (Cosma 2002).

At higher levels of chromatin organization, the three-dimensional arrangement of genes in the nuclear space also influences gene expression. Radial positioning of genes mostly correlates with states of expression, with active genes often located in the interior and silent genes at the periphery (Takizawa et al. 2008a; Takizawa et al. 2008b). However, radial

Editors: David L. Spector and Tom Misteli

Additional Perspectives on The Nucleus available at www.cshperspectives.org

Copyright (C) 2010 Cold Spring Harbor Laboratory Press; all rights reserved; doi: 10.1101/cshperspect.a000588

Cite this article as Cold Spring Harb Perspect Biol 2010;2:a000588 


\section{Ferrai et al.}

positioning of genes is unlikely to be a major determinant of gene expression per se, as chromatin regulator complexes do not display radial gradients of abundance, but are instead homogenously distributed or preferentially localized in nuclear subcompartments. The association of inactive genes with the nuclear periphery, which is enriched for transcriptionally silent heterochromatin in most cell types, suggests a molecular mechanism for gene repression. For example, the human CFTR gene associates with peripheral heterochromatin in cell types where the locus is silent, but occupies more internal positions in cell types where CFTR is expressed (Zink et al. 2004). In contrast, the highly conserved murine CFTR homologue and adjacent genes are more centrally positioned irrespective of their expression (Sadoni et al. 2008), possibly because of chromosomal arrangement constraints outside of the Cftr locus. A correlation between gene silencing and positioning at the nuclear periphery has also been shown for several differentiationspecific genes in various cell systems (Brown et al. 1999; Skok et al. 2001; Kosak et al. 2002; Kim et al. 2004; Williams et al. 2006). More recently, the silencing effect of direct associations to the nuclear lamina have been investigated by artificial tethering of reporter genes (Andrulis et al. 1998; Finlan et al. 2008; Reddy et al. 2008). Many genes are inactivated in response to an induced association to the lamina, despite other genes remaining active; these conflicting responses suggest that individual genes have differential sensitivity to the silencing mechanisms at the periphery.

Gene neighborhoods constitute a major determinant of gene positioning as each gene is not free to establish its preferred position, but responds to the properties of neighboring genes in the same chromosome. Chromosomes occupy discrete territories within the interphase nucleus in preferred, yet nondeterministic positions that correlate with cell type-specific patterns of gene expression (Cremer et al. 1982; Parada and Misteli 2002). Painting of whole chromosomes in human activated lymphocytes, at high-resolution using a fluorescence in situ hybridization (FISH) approach on ultrathin cryosections, shows that $\sim 20 \%$ of the nuclear volume contains intermingled chromatin from neighboring chromosomes, and that a specific inducible locus (MHCII) can be positioned within other CTs (Branco and Pombo 2006). The close spatial proximity between chromosomes has cell type specificity and correlates with increased translocation probability (Roix et al. 2003; Kuroda et al. 2004; Osborne et al. 2007).

Chromosome positioning depends on the physical constraints of packaging large chromatin polymers within a small nuclear volume, and is influenced by cell-type specific gene expression programs. In spherical nuclei, such as lymphocytes, the radial positioning of chromosomes correlates with their gene density, with gene-dense and gene-poor chromosomes positioned centrally or at the periphery, respectively (Boyle et al. 2001; Branco et al. 2008). In cells with flat nonspherical nuclei, such as fibroblasts, the size of the chromosome correlates with the radial position, with smaller chromosomes occupying central positions of the nucleus and larger chromosomes positioned toward the periphery independently of gene density (Bolzer et al. 2005).

Gene expression is generally controlled by the combinatorial binding of a multitude of transcription factors to specific DNA sequences, which can be located either immediately upstream of protein coding sequences (at promoters) or at considerable distances, upstream or downstream, from the gene. For example, the locus-control region (LCR) at the murine $\beta$-globin cluster is located $\sim 60 \mathrm{~kb}$ upstream of the adult $\beta$ major globin gene (Hbbl) (Dean 2006). Activating transcription factors act either by promoting interactions between transcription start sites and RNA polymerase (RNAP) enzymes or associated transcription machineries, or by recruiting chromatin modifiers that establish local open chromatin states, which are permissive for transcription (Szutorisz et al. 2005). The complex three-dimensional network of chromatin interactions likely reflects the transcriptional program of the cell, in which genes assume "on" or "off" states according to their local chromatin associations and to their 
positioning within specific nuclear neighborhoods with activating or silencing features, respectively (Fig. 1) (Dillon 2006; Misteli 2007).

\section{GENE POSITIONING AT THE LOCAL LEVEL: CHROMATIN INTERACTIONS BETWEEN REGULATORY ELEMENTS}

The transcriptional activation of genes is often described by the simple binding of transcription factors to specific regulatory sequences at variable distances from transcription start sites, followed by the recruitment of RNAP and associated regulatory factors. Novel methodological approaches have enabled the identification of long-range chromatin interactions between regulatory elements and the genes they regulate across the genome, thereby permitting the study of gene regulation in three dimensions. A major breakthrough in this area was the development of the chromosome conformation capture (3C) method, a molecular approach first used to study the three-dimensional folding of Saccharomyces cerevisiae chromosome III (Dekker et al. 2002). In the 3C technique, chromatin is extracted from whole nuclei after chemical cross-linking of DNA-protein complexes and digestion with restriction enzymes or sonication. Intermolecular DNA ligation at low DNA concentration promotes ligation between protein-crosslinked DNA fragments because of their local proximity (Dekker et al. 2002). Interaction partners can then be identified using primers.

3C-based technologies have been extensively used to examine the mechanism of gene regulation at the $\beta$-globin gene cluster where the LCR and additional hypersensitive sites form an active chromatin hub with the $\mathrm{Hbbl}$ promoter in a tissue-specific manner (Tolhuis et al. 2002). The conformation of the active hub changes throughout erythrocyte development, in agreement with gene activity at the locus (Palstra et al. 2003), and is dependent on specific regulatory factors (Drissen et al. 2004; Vakoc et al. 2005; Splinter et al. 2006). These findings illustrate that intrachromosomal associations, driven by specific interactions between chromatin binding factors, are an additional feature of gene regulation. 3C-based approaches have also been widely used to show long-range chromatin interactions at other loci, specifically between distal enhancers and gene promoters (Eivazova and Aune 2004; Spilianakis and Flavell 2004; Liu and Garrard 2005; Amano et al. 2009), but also between promoter and terminator sequences of the same gene, dependent on RNAPII (O'Sullivan et al. 2004; Tan-Wong et al. 2009).

Chromatin looping has also been observed at silencers, insulators and boundary elements, which are thought to limit the interaction of enhancers to their target gene promoters. For example, differentially methylated regions (DMRs), involved in the control of parental specific gene expression, establish specific loop structures that may partition differentially expressed genes into distinct loops of active versus silent domains (Murrell et al. 2004). Cell-type specific chromatin interactions mediated by chromatin-associated proteins such as Polycomb repressor complexes, SATB1 and 2, CTCF, and cohesins, have also been identified. For example, cohesin and CTCF binding sites at the developmentally regulated cytokine locus IFN $\gamma$, in human $\mathrm{T}_{\mathrm{H}} 1$ lymphocytes, correlate with chromatin interactions in cis, although CTCF is not sufficient to maintain these interactions in the absence of cohesin (Hadjur et al. 2009).

\section{GENE POSITIONING AT HIGHER LEVEL: CHROMATIN INTERACTIONS BETWEEN DISTAL GENES}

Chromatin interactions between functionally related genes on the same or different chromosomes have also been described by both 3Cbased approaches and by single-cell imaging using FISH. The most extensively studied example is that of the murine $\beta$-globin gene, $H b b 1$, which has been shown to interact with other erythroid-specific genes, Eraf and Uros that are located approximately $40 \mathrm{Mb}$ downstream of Hbb1 on chromosome 7 (Osborne et al. 2004; Simonis et al. 2006). Although it remains unclear whether such interactions are necessary for the correct temporal onset of erythroid 
C. Ferrai et al.
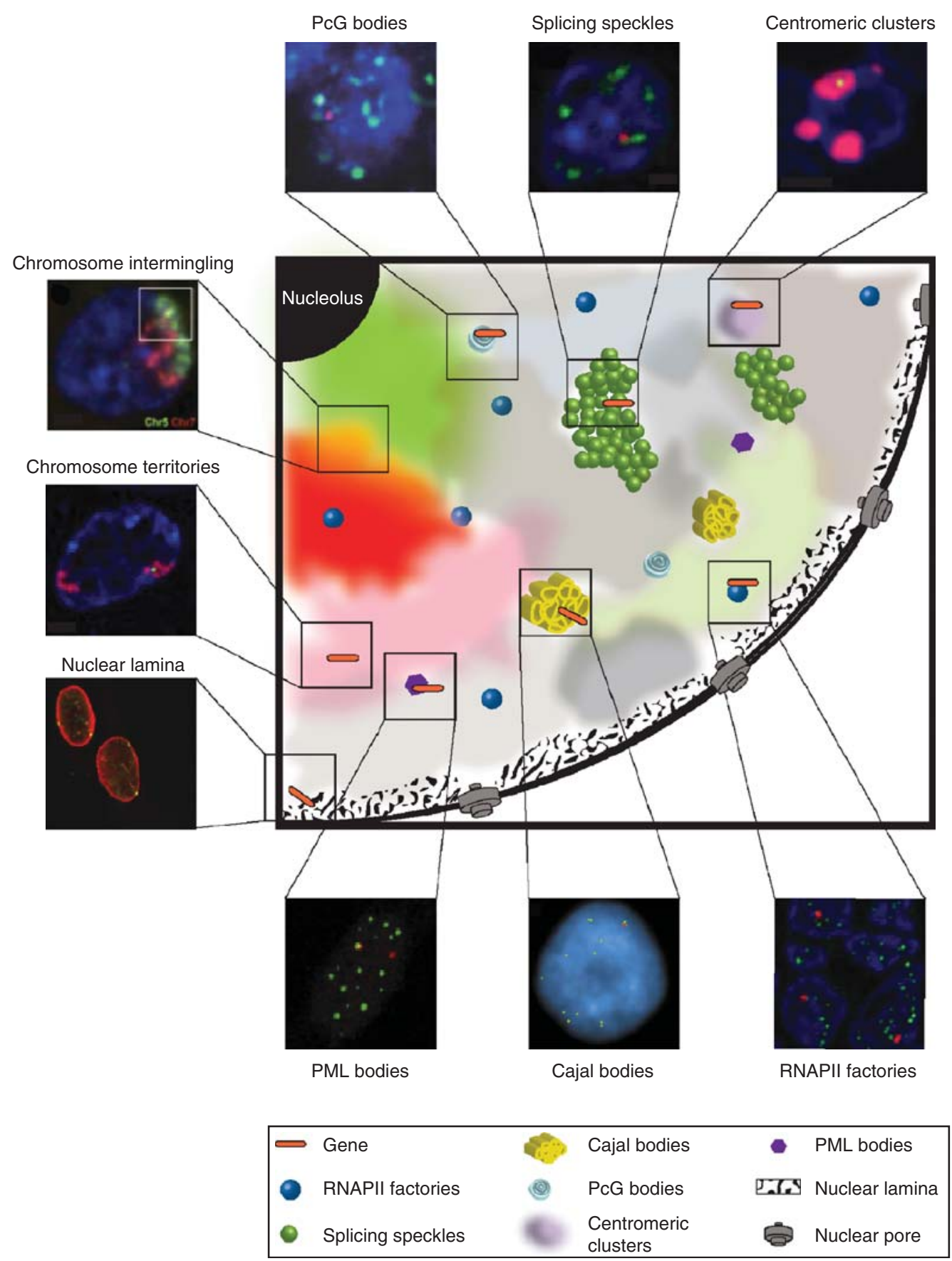

Figure 1. Nuclear subcompartments. An illustration of the mammalian cell nucleus showing nuclear domains and features of gene positioning (orange bar) that have been identified thus far. The nuclear positioning of genes and their associations with different nuclear landmarks are implicated in gene activation and gene repression as discussed in the text. DNA counterstain in blue where applicable. Centromeric clusters. Human CD2 transgenes (green) colocalize with a centromeric cluster (red) in nonexpressing $\mathrm{T}$ cells from hCD2 transgenic mice (line 1.3A14). Reprinted by permission from (Hiragami-Hamada et al. 2009). 
transcription, they appear to involve transcription factories (Osborne et al. 2004; Schoenfelder et al. 2010) or the larger splicing speckles (Brown et al. 2006; Brown et al. 2008; Hu et al. 2009). Both compartments are associated with phosphorylated forms of RNAPII (Xie et al. 2006), but transcription factories are active sites of transcription containing many active RNAPs and associated nascent transcripts (Iborra et al. 1996; Jackson et al. 1998; Pombo et al. 1999), whereas splicing speckles are enriched for a pool of splicing factors and RNAPII complexes that remain stably associated upon transcriptional inhibition (Hall et al. 2006; Xie et al. 2006; Lawrence and Clemson 2008). Association of speckles with highly active genes or with genes that have complex splicing reactions (Xing et al. 1995; Jolly et al. 1999; Smith et al. 1999; Johnson et al. 2000; Shopland et al. 2002; Shopland et al. 2003; Hall et al. 2006; Smith et al. 2007) suggests that gene proximity to splicing speckles may increase the efficiency of RNA splicing and thereby influence the levels of gene expression.

Other interchromosomal associations between genes, which correlate with either gene activation or repression, have been described in many different systems (Harmon and Sedat 2005; Spilianakis et al. 2005; Bacher et al. 2006; Ling et al. 2006; Lomvardas et al. 2006; $\mathrm{Xu}$ et al. 2006; Apostolou and Thanos 2008; Noordermeer et al. 2008; Schoenfelder et al. 2010). The initial 3C technique revealed many interesting long-range interactions but was limited to the analyses of a small number of sequences requiring prior knowledge of both interacting baits. Developments of the 3C technique, including circular chromosomal conformation capture (Zhao et al. 2006) and chromosome conformation capture-on-chip (Simonis et al. 2006) (both called 4C), use inverse PCR primers to amplify circular DNA obtained by the ligation of two proximal segments of chromatin. These extended applications of 3C technology enable the simultaneous identification of many interactions using single known baits. Unbiased genome-wide strategies have also emerged. In yeast high-throughput sequencing of 3C-ligation products and bioinformatic identification of ligated fragments has revealed novel chromatin arrangements (Rodley et al. 2009). Two independent approaches in mammalian systems, Hi-C (Lieberman-Aiden et al. 2009) and chromatin interaction analysis by paired-end tag sequencing (ChIA-PET) (Fullwood et al. 2009) have allowed unbiased identification of ligation products by tagging the ligation junction and then enriching the region using affinity purification. In contrast to $\mathrm{Hi}-\mathrm{C}$, the ChIA-PET approach enriches 3C products associated with a specific protein of interest thereby identifying protein-based interchromatin networks.

One inherent limitation of the 3C-derived approaches is its population-based analysis

Figure 1. (Continued) Splicing speckles. The C3/C4 genomic region of murine chromosome 8 (red) associates with splicing speckles (green) in fetal liver cells. Reprinted by permission from (Noordermeer et al. 2008). PcG bodies. Bxd gene (red) positioned at PcG bodies (green) in the posterior part of wild-type stage 5-8 hour Drosophila embryos examined by 2D-FISH. Reprinted by permission from Macmillan Publishers Ltd: Nature Cell Biology (Lanzuolo et al. 2007), copyright (2007). Chromosome intermingling. Intermingling between chromosomes 5 (green) and 7 (red) in human lymphocytes. Reproduced with permission from (Branco and Pombo 2006). Chromosome territories. UPA locus (green) is positioned inside of its chromosome territory (CT; chromosome 10, red) in HepG2 cells. Reproduced with permission from (Ferrai et al. 2010). Nuclear lamina. Igh locus (green) interaction with the nuclear lamina (LMNB1, red) in NIH3T3. Reprinted by permission from Macmillan Publishers Ltd: Nature (Reddy et al. 2008), copyright (2008). PML bodies. MHCII region (red) is proximal to PML bodies (green) in control fibroblasts. Reproduced with permission from (Shiels et al. 2001). Cajal bodies. Simultaneous hybridization of $R N U 1, R N U 2, R N U 3, R N U 7, R N U 12$, HIST1, and HIST2 loci show several simultaneous gene interactions with Cajal bodies (red). Reprinted from (Frey et al. 1999). Copyright (1999), with permission from Elsevier. RNAPII factories. Association of hCD2 transgenes with RNAPII-S2p in T cells from hCD2 transgenic mouse line 1.3B (SQ Xie, R Festenstein, A Pombo, unpubl.). 
C. Ferrai et al.

that gives rise to average maps of chromatin interactions unlikely to exist in an individual cell. High resolution analyses of physical proximity between 3C partners using cryo-FISH (Simonis et al. 2006) or confocal microscopy (Lieberman-Aiden et al. 2009; Schoenfelder et al. 2010) show remarkably low frequencies of association at distances below $500 \mathrm{~nm}$, which are not consistent with close molecular interactions. Chromatin associations detected by 3C may not always be directly related to regulatory interactions, but may be inherent to chromosome organization and/or promoted by independent coassociation to large nuclear structures. Cytological approaches that measure the frequency of locus-specific interactions at the single cell level remain an important complement to molecular 3C approaches, albeit limited to the analyses of few sequences.

\section{GENE POSITIONING RELATIVE TO SITES OF TRANSCRIPTION: TRANSCRIPTION FACTORIES}

Different classes of genes are transcribed by the three nuclear RNAPs type I, II, or III: RNAPI transcribes the $45 \mathrm{~S}$ ribosomal RNA genes tandemly repeated in the genome, RNAPII transcribes messenger RNAs and small structural RNAs, and RNAPIII transcribes the 5S rRNA, transfer RNA and other small structural RNA genes.

Visualization of transcriptional activity after pulse-labeling of tagged nucleotides showed that genes are active in distinct subnuclear domains termed transcription factories (Jackson et al. 1993; Wansink et al. 1993). The limited number of transcription sites per nucleus as compared with the larger number of active transcription units suggests that many active RNAPs and associated transcription units are present in each transcription factory (Iborra et al. 1996; Jackson et al. 1998; Kimura et al. 1999; Pombo et al. 1999). Evidence that most active genes are associated with only one or a few active RNAPs at any given time led to the idea that each transcription factory simultaneously transcribes more than one gene (Cook 1999). Support for this model initially came from observations that $H b b 1$, Eraf, and Uros genes, separated by several Mb, coassociate in a shared factory when transcribed (Osborne et al. 2004). A recent analysis of a larger number of genes in the same cell type shows proximity between $H b b 1$ and additional genes separated by large genomic regions within the same chromosome and between genes from different chromosomes, albeit specific associations are not required for transcriptional activity of the genes analyzed (Schoenfelder et al. 2010). Other studies also support the functional specialization of transcription factories, depending on the type of RNAP (Pombo et al. 1999), gene structure (Xu and Cook 2008) (Schoenfelder et al. 2010), or activation state of RNAPII (Ferrai et al. 2010).

\section{GENE POSITIONING RELATIVE TO NUCLEOPLASMIC SUBCOMPARTMENTS}

\section{Splicing Speckles}

Splicing speckles are major subnuclear compartments characterized by an accumulation of components of the splicing machinery, polyA ${ }^{+}$RNA and numerous mRNA metabolic factors, as well as RNAPII (Hall et al. 2006; Xie et al. 2006; Lawrence and Clemson 2008). Several splicing speckle domains $(\sim 10-30)$ are typically present in each nucleus, measuring $0.5-3 \mu \mathrm{m}$ in diameter and occupying $5 \%-10 \%$ of the nucleoplasmic volume (Spector 1993; Fay et al. 1997; Xie et al. 2006).

Subchromosomal R bands, containing $\sim 2$ $10 \mathrm{Mb}$ blocks of gene-rich genomic sequence, are frequently found associated with speckles (Shopland et al. 2003). A subset of genes such as heat-shock genes, erythroid specific genes, collagen genes, and muscle specific genes preferentially associate with SC35 domains when active (Xing et al. 1995; Jolly et al. 1999; Smith et al. 1999; Johnson et al. 2000; Shopland et al. 2002; Shopland et al. 2003; Hall et al. 2006; Smith et al. 2007). In vivo studies using multicopy BAC transgenes, containing the inducible $H s p 70$ gene tagged with Lac operator sequences and visualized on GFP-LacI expression, show increased association of the transgene with 
splicing speckles within $30 \mathrm{~min}$ of heat shock activation (Hu et al. 2009).

Coassociation of genes that share the same pathway has been observed at speckles in skeletal muscle and in erythroid cells. The musclespecific genes, myf-4, MyoD, and $c M y H C$, important for skeletal muscle differentiation, localize to SC35 domains in differentiated muscle cells, but not in the undifferentiated satellite myoblasts or fibroblasts (Moen et al. 2004). Erythroid genes, $\mathrm{Hbb}, \mathrm{Hba}$, Eraf, Slc4al, and Gata1, located on four different murine chromosomes, have also been found nonrandomly positioned relative to common splicing speckles (Brown et al. 2008). Importantly, the association with speckles of genes that have complex splicing reactions and the accumulation of unspliced RNAs at these sites (Johnson et al. 2000; Smith et al. 2007) suggests that gene associations with speckles may influence the yield of mature mRNAs.

\section{Cajal Bodies and PML Bodies}

Cajal bodies are nucleoplasmic structures, typically one to six per nucleus, with diameters of 0.1-1 $\mu \mathrm{m}$ (Gall 2003). They are involved in the biogenesis of several classes of spliceosomal small nuclear ribonucleoprotein particles (snRNPs) and are enriched in RNAP subunits, specific basal transcription factors, and RNA processing factors.

U2 snRNA genes associate within Cajal bodies in a mechanism that depends on the $\mathrm{U} 2$ gene promoter and is thought to be important for the maturation of newly synthesized U2 snRNAs (Frey et al. 1999; Smith and Lawrence 2000; Frey and Matera 2001). In vivo imaging of U2 snRNA arrays showed that they only associate with Cajal bodies upon induction. The mechanism involves long-range movements toward relatively stably positioned Cajal bodies and is thought to be mediated by actin polymerization (Dundr et al. 2007).

Cajal bodies contain the U7 snRNP, a key component of the histone mRNA 3 '-end formation machinery (Frey and Matera 1995). Although replication-dependent histone genes that are cell-cycle regulated, including HIST1 and HIST2 multigene clusters, associate with Cajal bodies, their transcriptional activity is not dependent on this association, which appears to be mediated by the nascent transcripts (Jacobs et al. 1999; Schul et al. 1999; Liu et al. 2006; Stanek and Neugebauer 2006). In contrast, cell cycle-independent histone genes, such as $H 3.3 A$, which are constitutively active and produce polyadenylated transcripts, do not associate with Cajal bodies (Shopland et al. 2001).

Promyelocytic leukemia nuclear bodies (PML) are nuclear multiprotein domains, (Five to 30 per nucleus) with diameters between $0.1-1.0 \mu \mathrm{m}$ that can vary in relation to the cell cycle stage and cell type (Bernardi and Pandolfi 2007). PML bodies contain many proteins and have been implicated in multiple regulatory pathways, from the control of cell proliferation to DNA repair or apoptosis, and in viral infection. PML bodies colocalize with the TP53 locus (tumor protein 53 gene) in Jurkat cells, raising the possibility that PML bodies play a role in regulating TP53 transcription (Sun et al. 2003). Interaction with PML bodies has also been detected in living cells (Tsukamoto et al. 2000), but ongoing transcription appeared independent of PML body association (Tsukamoto et al. 2000). Furthermore, the analysis of multiple genomic regions showed that PML bodies associate with genomic regions characterized by high transcriptional activity (Wang et al. 2004). However, detection of active alleles by RNA-FISH revealed that transcriptional activity is independent of gene association with PML bodies, and PML knock-down does not alter transcription levels (Wang et al. 2004), suggesting that expression does not require association with PML bodies.

\section{Polycomb Bodies}

Polycomb group $(\mathrm{PcG})$ complexes are involved in heritable gene repression by epigenetic chromatin modifications and by regulating the nuclear organization of their target genes (Schuettengruber et al. 2007). In mammalian and Drosophila cells, several PcG proteins have a nonhomogeneous distribution in the 
C. Ferrai et al.

nucleoplasm being enriched in discrete foci called PcG bodies (Saurin et al. 1998; Orlando 2003), which can be preferentially localized near centromeric heterochromatin (Saurin et al. 1998). Whole-mount FISH in Drosophila melanogaster embryos showed that Polycomb response elements (PREs) such as Fab-7 or $b x d$ of the inactive homeotic bithorax complex (BX-C) colocalize with PcG bodies in more than $80 \%$ of the anterior nuclei (Lanzuolo et al. 2007). In the posterior part of the embryo, inactive PREs $(b x d)$ remain predominately bound to PcG bodies, whereas active elements $(F a b-7)$ clearly lose contact with these domains, supporting the idea that gene association with PcG bodies is important for gene silencing. The pairing of two Fab-7 PREs from different genomic regions, as well as the coassociation of three PREs (Fab-7, Mcp, and $b x d$ ) within the BX-C Hox gene locus, occur within shared PcG bodies (Grimaud et al. 2006; Lanzuolo et al. 2007). A coassociation of several PcG regulated genes in PcG bodies is also suggested by the existence of fewer PcG bodies than PcG target genes identified by genome-wide chromatin immunoprecipitation (ChIP) (Sexton et al. 2009), further supporting the idea that repositioning of genomic regions with respect to nuclear compartments may be important for the regulation of gene expression. ChIP analysis of a major Polycomb protein, Enhancer of Zeste (Ezh2), combined with 3C showed that Ezh2 is present at intra- and interchromosomal hubs that are associated with gene silencing (Tiwari et al. 2008a; Tiwari et al. 2008b).

\section{Centromeric Heterochromatin Regions}

Gene associations with centromeric heterochromatin regions also correlate with gene silencing. Brown and colleagues analyzed the nuclear position of several genes $(C D 2, \lambda 5$, $C D 8 \alpha$, Rag, Sox1 and Hoxb4-b9) relative to centromeric regions in mature B lymphocytes, before and following mitogenic CD40mediated activation (Brown et al. 1999). Genes that are not expressed in mature B cells $(\lambda 5$, $C D 8 \alpha$, Rag, Sox1, and Hoxb4-b9) were not associated with centromeric chromatin in resting mature B cells, but became juxtaposed to these domains in cycling mature B cells after mitogenic stimulation. The CD2 gene, which is widely expressed in mature B lymphocytes, remained distant from centromeric domains irrespectively of stimulation. These findings indicate that some inactive genes become associated with centromeric heterochromatic regions during cell division.

Analyses of Rag and TdT genes, expressed in $\mathrm{CD} 4^{+} \mathrm{CD} 8^{+}$thymocytes but down-regulated on T-cell receptor engagement, showed repositioning of these genes to centromeric regions during induced differentiation, resulting in heritable silencing (Brown et al. 1999). Surprisingly, transient silencing of Rag and $T d T$ in a transformed thymocyte cell line was reversible and was not accompanied by repositioning of these genes to centromeric regions, implicating that silencing is initiated through a more complex mechanism. Genes also reposition to centromeric regions on allelic exclusion during B-cell maturation (Skok et al. 2001). In immature B lymphocytes, $I g H$ and $I g L$ alleles are not associated with centromeric regions, but become associated with these regions upon allelic exclusion which leads to B cells expressing functional receptors encoded by a single $\operatorname{IgH}$ allele and one of four $I g L$ alleles. The repositioning of genes to centromeric regions is proposed to be mediated through a DNA binding protein, Ikaros/Lyf-1, which is important for lymphocyte development (Brown et al. 1997; Brown et al. 1999). Nevertheless, transgenes integrated in centromeric regions, are not always silenced (Sabbattini et al. 2001). The mouse $\lambda 5$ and $V_{\text {preB } 1}$ genes are expressed in pro- and pre-B cells but silenced in immature and mature $\mathrm{B}$ cells, where they are relocated to centromeric regions. A

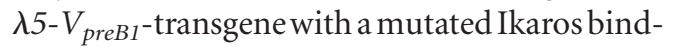
ing site was released from Ikaros-mediated silencing (Sabbattini et al. 2001). Interestingly, the integration of the mutated $\lambda 5-V_{\text {preB1 }}{ }^{-}$ transgene into centromeric heterochromatin region does not restore silencing at the mature B-cell stage (Sabbattini et al. 2001), showing that transcription can take place in centromeric regions and Ikaros' pivotal role in mediating $\lambda 5-V_{\text {preB1 }}$-silencing on B-cell differentiation. 
Nuclear Lamina

The nuclear lamina underlays the inner nuclear membrane and consists of type $\mathrm{V}$ intermediate filament proteins called nuclear lamins (Dechat et al. 2008). Markers of gene repression, such as enrichment for hypoacetylated chromatin (Sadoni et al. 1999), depletion of both RNAPII and the open chromatin histone modification H3K4me2 (dimethylation of lysine 4 of histone 3 ) are associated with the nuclear lamina (Luco et al. 2008). Genome-lamina interactions in human occur through more than 1,300 sharply defined large chromatin domains, referred to as lamina associated domains (LADs) (Guelen et al. 2008). These domains are 0.1$10 \mathrm{Mb}$ in size in human fibroblasts, are enriched five- 10-fold for genes with lower expression levels than genes outside LADs and are enriched in repressive histone marks, H3K27me3 (trimethylation of lysine 27 on histone 3) and H3K9me2 (dimethylation of lysine 9 on histone 3 ), but are depleted of the active histone mark H3K4me2.

Dynamic repositioning of some genes to the lamina correlates with changes in gene expression. Activation of genes including $\mathrm{Hbb}$ during differentiation of mouse erythroid cells (Ragoczy et al. 2006), $I g H$ and $\operatorname{IgK}$ in murine B-cell differentiation (Kosak et al. 2002) or Mash1 during murine neuronal differentiation (Williams et al. 2006), correlates with their separation from the repressive lamina environment. Interestingly, some genes initiate transcription while at the nuclear lamina before internal repositioning ( $\mathrm{Hbb}$ ) (Ragoczy et al. 2006) or remain in close proximity to the nuclear periphery upon activation (IFN $\gamma$ ) (Hewitt et al. 2004) indicating that the peripheral gene positioning per se is not restrictive for transcription.

Induced tethering of reporter genes to the nuclear lamina has shown in yeast and cultured mammalian cells the relevance of physical gene associations with the nuclear periphery for transcriptional activity (Andrulis et al. 1998; Finlan et al. 2008; Kumaran and Spector 2008; Reddy et al. 2008). Although some genes were repressed by the interaction with the nuclear periphery (Andrulis et al. 1998; Finlan et al.
2008; Reddy et al. 2008), others remained fully transcriptionally competent (Finlan et al. 2008; Kumaran and Spector 2008; Reddy et al. 2008). Finlan and colleagues showed that the mechanisms of repression at the nuclear periphery could be alleviated by inhibition of histone deacetylase (HDAC) activity without affecting gene association with the lamina (Finlan et al. 2008), indicating the importance of HDACs in promoting gene repression at the lamina. In all three mammalian studies, transgene repositioning required the passage through mitosis (Finlan et al. 2008; Kumaran and Spector 2008; Reddy et al. 2008). In summary, gene repression at the nuclear lamina is therefore not a general phenomenon but gene specific, depending on multiple parameters such as transcription factor accessibility, promoter strength, existence of insulator elements and pre-existing chromatin marks, which may counteract the mechanisms of transcription repression at the nuclear lamina.

Gene silencing mechanisms that correlate with chromatin association to the nuclear periphery have also been observed in lower eukaryotes (Akhtar and Gasser 2007; Towbin et al. 2009). In yeast nuclei, which do not have a nuclear lamina, repressive proteins such as Sir proteins (Sir2, Sir3, and Sir4) are known to interact with subtelomeric heterochromatic regions and such interactions are mostly confined to foci localized at the nuclear envelope. Transcription-dependent associations of specific groups of genes with nuclear pores have also been described from yeast to mammals, suggesting that the nuclear periphery promotes distinct functional environments compatible with both gene repression and activation.

\section{CHROMATIN DYNAMICS}

Live cell imaging in interphase nuclei shows that chromatin movements occur within a radius of $0.5-1.0 \mu \mathrm{m}$, which given the large size of the mammalian nucleus $(\sim 10 \mu \mathrm{m}$ diameter $)$ suggests that a given locus is constrained to a very small fraction of the total nuclear volume (Abney et al. 1997; Chubb et al. 2002; Walter et al. 2003). Larger chromatin movements 
$(>2 \mu \mathrm{m})$ were observed in early G1 phase of the cell cycle, suggesting that chromatin repositioning occurs during the re-establishment of interphase nuclear architecture (Walter et al. 2003). The importance and complexity of chromatin mobility in gene expression is highlighted in examples of gene looping out of their own chromosome territories (CTs) upon gene induction, such as observed for MHCII, EDC and Hox clusters and for the $u P A$ gene (Volpi et al. 2000; Chambeyron and Bickmore 2004; Williams et al. 2006; Ferrai et al. 2010).

The repositioning of Hox clusters B and D relative to their CTs and the condensation level of clusters have been studied during retinoic acid-induced differentiation of murine embryonic stem (ES) cells and in embryos (Chambeyron and Bickmore 2004; Chambeyron et al. 2005; Morey et al. 2007). Hox clusters extrude outside their territories and decondense concomitantly with expression. However, locus decondensation occurs independently of locus position relative to its CT and the HoxD locus is preferentially positioned at the CT interior in limb bud embryo cells (embryonic day 9.5) where it is active (Morey et al. 2007), suggesting that locus positioning relative to the CT may not always be important for gene expression upon induction. RNA-FISH experiments have shown that in the induced state active alleles locate inside, at the edge, and outside of the CT, with a preferential positioning of inactive alleles within the CT (Morey et al. 2009). A more recent analysis of the inducible $u P A$ gene in human HepG2 cells shows that it relocates out of the CT on activation with phorbol esters within 3 hours of treatment (Ferrai et al. 2010). In the active state, $u P A$ gene activity is independent of its position in relation to its CT. Unexpectedly, before tetradecanoyl phorbol acetate (TPA) induction of the gene, the majority of uninduced $u P A$ genes positioned inside the CT are silenced, whereas a small proportion of $u P A$ loci located outside of the CT are more likely to be transcribed. Collectively, these studies suggest that locus positioning inside the CT correlates in some situations with gene silencing, despite the presence of active RNAPII and transcription occurring throughout the volume of CTs (Abranches et al. 1998; Verschure et al. 1999; Verschure et al. 2003; Branco and Pombo 2006; Ferrai et al. 2010).

\section{ALTERED GENE POSITIONING IN DISEASE}

Nuclear architecture and chromatin structure are important features for the regulation of gene expression, and can be altered in diseases. Unbalanced levels or mutations of lamin proteins or emerin, an integral protein of the nuclear envelope, are linked to a group of rare genetic disorders called nuclear envelopathies (Webster et al. 2009). Well known nuclear envelopathies such as Hutchinson-Gilford progeria syndrome (HGPS; premature aging) and Emery-Dreifuss muscular dystrophy (EDMD) are associated with mutations of the lamin $\mathrm{A} / \mathrm{C}$ or emerin genes and are often characterized by alterations in nuclear morphology that affect chromatin organization and may compromise gene expression (Fig. 2A) (Webster et al. 2009).

Studies in primary fibroblasts of several nuclear envelopathies (including HGPS and EDMD) show the repositioning of chromosomes 13 and 18 toward the nuclear interior (Fig. 2B) (Meaburn et al. 2007). Repositioning of chromosome 18 to the nuclear interior and up-regulation of genes within this chromosome are also observed after lamin B1 knockout in mouse embryonic fibroblasts (Malhas et al. 2007). Aberrant chromosome distribution in envelopathies only affects specific tissues and cell lineages (Meaburn et al. 2007), as it is not observed in cell types such as cultured lymphoblastoid cells derived from patients with emerin and lamin A mutations (Boyle et al. 2001; Meaburn et al. 2005).

Repositioning of genes, small chromatin regions, or CTs is also seen in other diseases, such as facioscapulohumeral muscular dystrophy (FSHD) (Masny et al. 2004), immunodeficiency centromeric instability facial anomalities (ICF) (Matarazzo et al. 2007), epilepsy (Borden and Manuelidis 1988), or in male factor infertility (Finch et al. 2008). ICF syndrome is caused by mutations in DNA methyltransferase 3B (DNMT3B) and is associated with DNA 

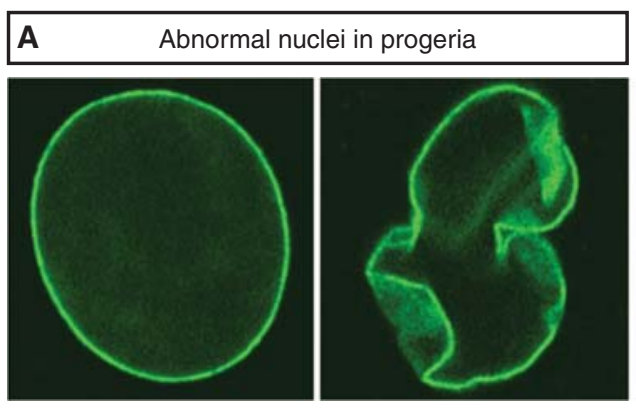

B Chromosome repositioning in progeria
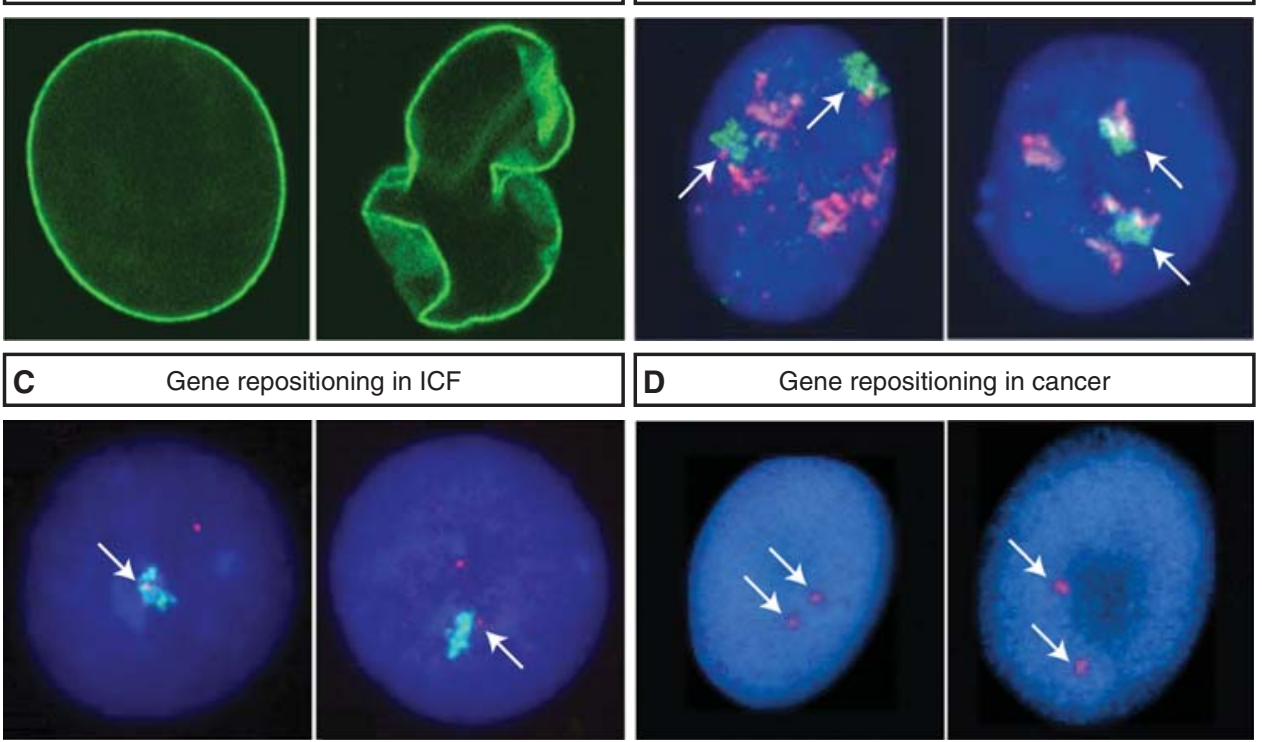

Gene repositioning in cancer

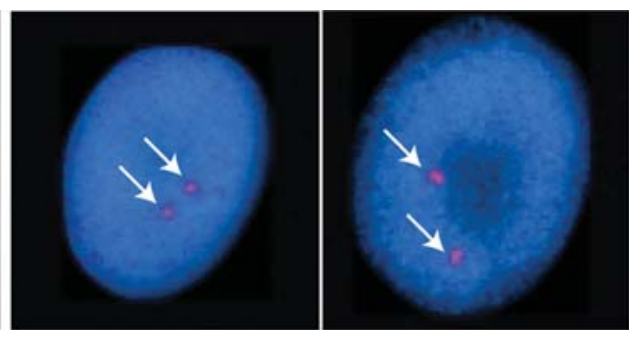

Figure 2. Nuclear organization defects in disease. (A) Abnormal nuclear shape in Hutchinson-Gilford Progeria Syndrome. Nuclei in patients with progeria show an abnormal morphology (right) contrasting with the regular nuclei shape found in healthy individuals (left). Reproduced with permission from (Scaffidi et al. 2005). (B) Chromosome repositioning in Hutchinson-Gilford Progeria Syndrome. Interior repositioning of human chromosome 13 (green, arrows) in a HGPS fibroblast cell line (right), in comparison to a control cell line (left). Proliferation marker pKi-67 (red). Reproduced with permission from (Meaburn et al. 2007). (C) Gene repositioning in immunodeficiency centromeric instability facial anomalies (ICF). In control male cells (left), the SYBL1 (red, arrows) inactive allele (Y chromosome) is localized inside or at the edge of the Y CT, whereas in ICF cells (right) it loops out of its CT and escapes silencing. Reproduced with permission from (Matarazzo et al. 2007). Copyright (2007) National Academy of Sciences. (D) Gene repositioning in early mammary tumorigenesis. Position of the cancer AKT1 locus (red, arrows) before (left) and after (right) oncogenic activation of an epithelial cell line. After activation there is a radial shift in the locus position toward the periphery. Reproduced with permission from (Meaburn and Misteli 2008).

hypomethylation at specific genomic sites, such as the SYBL1 gene promoter which becomes derepressed. Interestingly, in ICF male and female patients, the SYBL1 inactive allele, located on the $\mathrm{Y}$ and inactive $\mathrm{X}$ chromosome, respectively, relocates outside of its respective $\mathrm{CT}$, recapitulating the position of the active alleles (Fig. 2C) (Matarazzo et al. 2007). In females, but not in males, both inactive SYBL1 and its silent neighbor SPRY3 loop out from the CT, suggesting that the reorganization extends beyond the derepressed, hypomethylated gene (Matarazzo et al. 2007).

Altered chromosome positioning has also been associated with numerous types of cancer in which altered gene expression patterns lead to malignant transformation of the cell. Chronic leukemias are associated with enlarged nuclei in lymphoid cells (Rozycka et al. 1988). Abnormal relocation of chromosome 18 from the nuclear periphery to the interior has been documented in several types of tumor cell lines, including melanoma-derived line, cervix carcinoma, colon carcinoma, Hodgkin-derived cell line and colon carcinoma metastasis cells (Cremer et al. 2003). A radial shift of chromosome 8 and a significant change in its shape was observed in pancreatic neoplastic tissue as well as a radial shift of centromeric regions of chromosome 17 and HER2 domains in tumor 
C. Ferrai et al.

breast tissues (Wiech et al. 2005). Individual gene loci are also repositioned during early tumorigenesis. In vitro induction of tumorigenesis in early breast cancer showed altered positioning of a set of cancer-associated genes such as AKT1, BCL2, ERB2, and VEGF loci although no correlation was found between radial redistribution and gene activity level (Fig. 2D; (Meaburn and Misteli 2008). The altered positioning of genes has recently been analyzed in invasive breast cancers toward devising prognosis markers of cancer. Eight genes (HES5, ERBB2, MYC, FOSL2, HSP9OAA1, AKT1, $T G F B 3$, and $C S F 1 R$ ) were robustly repositioned in breast cancer affected patients in comparison to normal tissues (Meaburn et al. 2009).

The origin of chromosomal rearrangements has long been assumed to be a random process, in which a DNA break in one chromosome results in stochastic joining with a DNA segment of another chromosome by defective DNA repair. However, recurrent translocation partners in specific types of cancer have hinted for a contribution of proximal nuclear positioning of the loci involved. Chromosomes that are known to preferentially translocate in specific cell types are more often associated in the nucleus (Roix et al. 2003; Brianna Caddle et al. 2007). Furthermore, the extent of intermingling between specific pairs of chromosomes correlates with the frequency of translocations between the same chromosomes observed after ionizing radiation (Branco and Pombo 2006). Analyses of single genes close to or at translocation breakpoints have also shown that their nuclear positioning is more proximal in cell types where the translocation is observed (Neves et al. 1999; Nikiforova et al. 2000; Roix et al. 2003; Kuroda et al. 2004; Osborne et al. 2007). More recently, studies on anaplastic large cell lymphoma, often associated with $\mathrm{t}(2 ; 5)$ translocations, and prostate cancer, with frequent translocations between TMPRSS2 and ERG or ETV1, have shown a direct correlation between increased gene proximity upon transcription induction and translocation (Lin et al. 2009; Mani et al. 2009; Mathas et al. 2009). Considered together, these observations strongly support the notion that physical proximity of genomic regions, influenced by states of gene activity and cell-type specific genome architecture, can predispose translocations that are characteristic of specific cell types and cancers.

\section{CONCLUDING REMARKS}

The absence of "membrane-enclosed" subcompartments in the eukaryotic cell nucleus led to early notions that molecules and processes were randomly distributed within this cellular compartment. Work in past decades has shown many features of the structural and functional organization of the eukaryotic cell nucleus. Most nuclear events do not occur throughout the nucleoplasm, but are limited to specific and spatially defined sites (Cook 1999; Misteli 2007). The nuclear volume contains morphological distinct higher-order chromatin domains, such as CTs and condensed heterochromatin, and a number of proteinaceous subcompartments including transcription factories, nuclear lamina, the nucleolus, speckles, and Cajal bodies (Handwerger and Gall 2006). The physically distinct nature of each compartment not only contributes to spatial partitioning of the nuclear space, but also creates distinct functional subdomains within the nucleus.

The mechanisms by which spatial positioning of the genome contributes to functional regulation are far from understood, and represent one of the biggest challenges in modern molecular and cell biology. One possibility is that subcompartmentalization of the nucleus influences multiple parameters including transcription factor accessibility, promoter strength, existence of insulator elements and pre-existing chromatin marks, which cumulatively lead to the correct expression signature unique for each cell type.

\section{ACKNOWLEDGMENTS}

We thank Sheila Q. Xie, André Möller and Miguel R. Branco for help researching literature for this article, and the Medical Research Council (UK) for support. C.F. was a recipient of a Wellcome Trust Value in People (VIP) Award. 
I.J.C. is supported by Fundação para a Ciência e a Tecnologia (Portugal).

\section{REFERENCES}

Abney JR, Cutler B, Fillbach ML, Axelrod D, Scalettar BA. 1997. Chromatin dynamics in interphase nuclei and its implications for nuclear structure. J Cell Biol 137: 1459-1468.

Abranches R, Beven AF, Aragon-Alcaide L, Shaw PJ. 1998. Transcription sites are not correlated with chromosome territories in wheat nuclei. J Cell Biol 143: 5-12.

Akhtar A, Gasser SM. 2007. The nuclear envelope and transcriptional control. Nat Rev Genet 8: 507-517.

Amano T, Sagai T, Tanabe H, Mizushina Y, Nakazawa H, Shiroishi T. 2009. Chromosomal dynamics at the Shh locus: Limb bud-specific differential regulation of competence and active transcription. Dev Cell 16: $47-57$.

Andrulis ED, Neiman AM, Zappulla DC, Sternglanz R. 1998. Perinuclear localization of chromatin facilitates transcriptional silencing. Nature 394: 592-595.

Apostolou E, Thanos D. 2008. Virus Infection Induces NF-кB-dependent interchromosomal associations mediating monoallelic IFN-ßgene expression. Cell 134: 85-96.

Bacher CP, Guggiari M, Brors B, Augui S, Clerc P, Avner P, Eils R, Heard E. 2006. Transient colocalization of $\mathrm{X}$-inactivation centres accompanies the initiation of $\mathrm{X}$ inactivation. Nat Cell Biol 8: 293-299.

Bernardi R, Pandolfi PP. 2007. Structure, dynamics and functions of promyelocytic leukaemia nuclear bodies. Nat Rev Mol Cell Biol 8: 1006-1016.

Bolzer A, Kreth G, Solovei I, Koehler D, Saracoglu K, Fauth C, Muller S, Eils R, Cremer C, Speicher MR, et al. 2005. Three-dimensional maps of all chromosomes in human male fibroblast nuclei and prometaphase rosettes. PLoS Biol 3: e157.

Borden J, Manuelidis L. 1988. Movement of the X chromosome in epilepsy. Science 242: 1687-1691.

Boyle S, Gilchrist S, Bridger JM, Mahy NL, Ellis JA, Bickmore WA. 2001. The spatial organization of human chromosomes within the nuclei of normal and emerinmutant cells. Hum Mol Genet 10: 211-219.

Branco MR, Pombo A. 2006. Intermingling of chromosome territories in interphase suggests role in translocations and transcription-dependent associations. PLoS Biol 4: e138.

Branco MR, Branco T, Ramirez F, Pombo A. 2008. Changes in chromosome organization during PHA-activation of resting human lymphocytes measured by cryo-FISH. Chromosome Res 16: 413-426.

Brianna Caddle L, Grant JL, Szatkiewicz J, van Hase J, Shirley BJ, Bewersdorf J, Cremer C, Arneodo A, Khalil A, Mills KD. 2007. Chromosome neighborhood composition determines translocation outcomes after exposure to high-dose radiation in primary cells. Chromosome Res 15: 1061-1073.

Brown KE, Baxter J, Graf D, Merkenschlager M, Fisher AG. 1999. Dynamic repositioning of genes in the nucleus of lymphocytes preparing for cell division. Mol Cell 3: 207-217.

Brown JM, Green J, das Neves RP, Wallace HA, Smith AJ, Hughes J, Gray N, Taylor S, Wood WG, Higgs DR, et al. 2008. Association between active genes occurs at nuclear speckles and is modulated by chromatin environment. $J$ Cell Biol 182: 1083-1097.

Brown KE, Guest SS, Smale ST, Hahm K, Merkenschlager M, Fisher AG. 1997. Association of transcriptionally silent genes with Ikaros complexes at centromeric heterochromatin. Cell 91: 845-854.

Brown JM, Leach J, Reittie JE, Atzberger A, Lee-Prudhoe J, Wood WG, Higgs DR, Iborra FJ, Buckle VJ. 2006. Coregulated human globin genes are frequently in spatial proximity when active. J Cell Biol 172: 177-187.

Cairns BR. 2005. Chromatin remodeling complexes: Strength in diversity, precision through specialization. Curr Opin Genet Dev 15: 185-190.

Chambeyron S, Bickmore WA. 2004. Chromatin decondensation and nuclear reorganization of the HoxB locus upon induction of transcription. Genes Dev 18: $1119-1130$.

Chambeyron S, Da Silva NR, Lawson KA, Bickmore WA. 2005. Nuclear re-organisation of the Hoxb complex during mouse embryonic development. Development 132: 2215-2223.

Chubb JR, Boyle S, Perry P, Bickmore WA. 2002. Chromatin motion is constrained by association with nuclear compartments in human cells. Curr Biol 12: 439-445.

Cook PR. 1999. The organization of replication and transcription. Science 284: 1790-1795.

Cosma MP. 2002. Ordered recruitment: Gene-specific mechanism of transcription activation. Mol Cell 10: 227-236.

Cremer T, Cremer C, Baumann H, Luedtke EK, Sperling K, Teuber V, Zorn C. 1982. Rabl's model of the interphase chromosome arrangement tested in Chinese hamster cells by premature chromosome condensation and laser-UV-microbeam experiments. Hum Genet 60: $46-56$.

Cremer M, Kupper K, Wagler B, Wizelman L, von Hase J, Weiland Y, Kreja L, Diebold J, Speicher MR, Cremer T. 2003. Inheritance of gene density-related higher order chromatin arrangements in normal and tumor cell nuclei. J Cell Biol 162: 809-820.

Dean A. 2006. On a chromosome far, far away: LCRs and gene expression. Trends Genet 22: 38-45.

Dechat T, Pfleghaar K, Sengupta K, Shimi T, Shumaker DK, Solimando L, Goldman RD. 2008. Nuclear lamins: Major factors in the structural organization and function of the nucleus and chromatin. Genes Dev 22: 832-853.

Dekker J, Rippe K, Dekker M, Kleckner N. 2002. Capturing chromosome conformation. Science 295: 1306-1311.

Dillon N. 2006. Gene regulation and large-scale chromatin organization in the nucleus. Chromosome Res 14: 117-126.

Dorigo B, Schalch T, Kulangara A, Duda S, Schroeder RR, Richmond TJ. 2004. Nucleosome arrays reveal the two-start organization of the chromatin fiber. Science 306: $1571-1573$. 


\section{Ferrai et al.}

Drissen R, Palstra RJ, Gillemans N, Splinter E, Grosveld F, Philipsen S, de Laat W. 2004. The active spatial organization of the $\beta$-globin locus requires the transcription factor EKLF. Genes Dev 18: 2485-2490.

Dundr M, Ospina JK, Sung MH, John S, Upender M, Ried T, Hager GL, Matera AG. 2007. Actin-dependent intranuclear repositioning of an active gene locus in vivo. J Cell Biol 179: 1095-1103.

Eivazova ER, Aune TM. 2004. Dynamic alterations in the conformation of the Ifng gene region during $\mathrm{T}$ helper cell differentiation. Proc Natl Acad Sci U S A 101: 251-256.

Fay FS, Taneja KL, Shenoy S, Lifshitz L, Singer RH. 1997. Quantitative digital analysis of diffuse and concentrated nuclear distributions of nascent transcripts, SC35 and poly(A). Exp Cell Res 231: 27-37.

Ferrai C, Xie SQ, Luraghi P, Munari D, Ramirez F, Branco MR, Pombo A, Crippa MP. 2010. Poised transcription factories prime silent uPA gene prior to activation. PLoS Biol 8: e1000270.

Finch KA, Fonseka KG, Abogrein A, Ioannou D, Handyside AH, Thornhill AR, Hickson N, Griffin DK. 2008. Nuclear organization in human sperm: Preliminary evidence for altered sex chromosome centromere position in infertile males. Hum Reprod 23: 1263-1270.

Finlan LE, Sproul D, Thomson I, Boyle S, Kerr E, Perry P, Ylstra B, Chubb JR, Bickmore WA. 2008. Recruitment to the nuclear periphery can alter expression of genes in human cells. PLoS Genet 4: e1000039.

Frey MR, Matera AG. 1995. Coiled bodies contain U7 small nuclear RNA and associate with specific DNA sequences in interphase human cells. Proc Natl Acad Sci U S A 92: 5915-5919.

Frey MR, Matera AG. 2001. RNA-mediated interaction of Cajal bodies and U2 snRNA genes. J Cell Biol 154: 499-509.

Frey MR, Bailey AD, Weiner AM, Matera AG. 1999. Association of snRNA genes with coiled bodies is mediated by nascent snRNA transcripts. Curr Biol 9: 126-135.

Fullwood MJ, Liu MH, Pan YF, Liu J, Xu H, Mohamed YB, Orlov YL, Velkov S, Ho A, Mei PH, et al. 2009. An oestrogen-receptor- $\alpha$-bound human chromatin interactome. Nature 462: 58-64.

Gall JG. 2003. The centennial of the Cajal body. Nat Rev Mol Cell Biol 4: 975-980.

Grimaud C, Bantignies F, Pal-Bhadra M, Ghana P, Bhadra U, Cavalli G. 2006. RNAi components are required for nuclear clustering of Polycomb group response elements. Cell 124: 957-971.

Guelen L, Pagie L, Brasset E, Meuleman W, Faza MB, Talhout W, Eussen BH, de Klein A, Wessels L, de Laat W, et al. 2008. Domain organization of human chromosomes revealed by mapping of nuclear lamina interactions. Nature 453: 948-951.

Hadjur S, Williams LM, Ryan NK, Cobb BS, Sexton T, Fraser P, Fisher AG, Merkenschlager M. 2009. Cohesins form chromosomal cis-interactions at the developmentally regulated IFNG locus. Nature 460: 410-413.

Hall LL, Smith KP, Byron M, Lawrence JB. 2006. Molecular anatomy of a speckle. Anat Rec A Discov Mol Cell Evol Biol 288: $664-675$.
Handwerger KE, Gall JG. 2006. Subnuclear organelles: New insights into form and function. Trends Cell Biol 16: $19-26$.

Harmon B, Sedat J. 2005. Cell-by-cell dissection of gene expression and chromosomal interactions reveals consequences of nuclear reorganization. PLoS Biol 3: e67.

Hewitt SL, High FA, Reiner SL, Fisher AG, Merkenschlager M. 2004. Nuclear repositioning marks the selective exclusion of lineage-inappropriate transcription factor loci during $\mathrm{T}$ helper cell differentiation. Eur J Immunol 34: 3604-3613.

Hiragami-Hamada K, Xie SQ, Saveliev A, Uribe-Lewis S, Pombo A, Festenstein R. 2009. The molecular basis for stability of heterochromatin-mediated silencing in mammals. Epigenetics Chromatin 2: 14.

Hu Y, Kireev I, Plutz M, Ashourian N, Belmont AS. 2009. Large-scale chromatin structure of inducible genes: Transcription on a condensed, linear template. J Cell Biol 185: 87-100.

Iborra FJ, Pombo A, Jackson DA, Cook PR. 1996. Active RNA polymerases are localized within discrete transcription "factories" in human nuclei. J Cell Sci 109: 1427-1436.

Jackson DA, Hassan AB, Errington RJ, Cook PR. 1993. Visualization of focal sites of transcription within human nuclei. Embo J 12: 1059- 1065.

Jackson DA, Iborra FJ, Manders EM, Cook PR. 1998. Numbers and organization of RNA polymerases, nascent transcripts, and transcription units in HeLa nuclei. Mol Biol Cell 9: 1523-1536.

Jacobs EY, Frey MR, Wu W, Ingledue TC, Gebuhr TC, Gao L, Marzluff WF, Matera AG. 1999. Coiled bodies preferentially associate with U4, U11, and U12 small nuclear RNA genes in interphase HeLa cells but not with U6 and U7 genes. Mol Biol Cell 10: 1653-1663.

Johnson C, Primorac D, McKinstry M, McNeil J, Rowe D, Lawrence JB. 2000. Tracking COL1A1 RNA in osteogenesis imperfecta. splice-defective transcripts initiate transport from the gene but are retained within the SC35 domain. J Cell Biol 150: 417-432.

Jolly C, Vourc'h C, Robert-Nicoud M, Morimoto RI. 1999. Intron-independent association of splicing factors with active genes. J Cell Biol 145: 1133-1143.

Kim SH, McQueen PG, Lichtman MK, Shevach EM, Parada LA, Misteli T. 2004. Spatial genome organization during T-cell differentiation. Cytogenet Genome Res 105: 292-301.

Kimura H, Tao Y, Roeder RG, Cook PR. 1999. Quantitation of RNA polymerase II and its transcription factors in an HeLa cell: Little soluble holoenzyme but significant amounts of polymerases attached to the nuclear substructure. Mol Cell Biol 19: 5383-5392.

Kosak ST, Skok JA, Medina KL, Riblet R, Le Beau MM, Fisher AG, Singh H. 2002. Subnuclear compartmentalization of immunoglobulin loci during lymphocyte development. Science 296: 158-162.

Kumaran RI, Spector DL. 2008. A genetic locus targeted to the nuclear periphery in living cells maintains its transcriptional competence. J Cell Biol 180: 51-65.

Kuroda M, Tanabe H, Yoshida K, Oikawa K, Saito A, Kiyuna T, Mizusawa H, Mukai K. 2004. Alteration of 
chromosome positioning during adipocyte differentiation. J Cell Sci 117: 5897-5903.

Lanzuolo C, Roure V, Dekker J, Bantignies F, Orlando V. 2007. Polycomb response elements mediate the formation of chromosome higher-order structures in the bithorax complex. Nat Cell Biol 9: 1167-1174.

Lawrence JB, Clemson CM. 2008. Gene associations: True romance or chance meeting in a nuclear neighborhood? J Cell Biol 182: 1035-1038.

Lieberman-Aiden E, van Berkum NL, Williams L, Imakaev M, Ragoczy T, Telling A, Amit I, Lajoie BR, Sabo PJ, Dorschner MO, et al. 2009. Comprehensive mapping of long-range interactions reveals folding principles of the human genome. Science 326: 289-293.

Lin C, Yang L, Tanasa B, Hutt K, Ju BG, Ohgi K, Zhang J, Rose DW, Fu XD, Glass CK, et al. 2009. Nuclear receptorinduced chromosomal proximity and DNA breaks underlie specific translocations in cancer. Cell 139: 1069-1083.

Ling JQ, Li T, Hu JF, Vu TH, Chen HL, Qiu XW, Cherry AM, Hoffman AR. 2006. CTCF mediates interchromosomal colocalization between Igf2/H19 and Wsb1/Nf1. Science 312: $269-272$.

Liu Z, Garrard WT. 2005. Long-range interactions between three transcriptional enhancers, active $V \kappa$ gene promoters, and a $3^{\prime}$ boundary sequence spanning 46 kilobases. Mol Cell Biol 25: 3220-3231.

Liu JL, Murphy C, Buszczak M, Clatterbuck S, Goodman R, Gall JG. 2006. The Drosophila melanogaster Cajal body. J Cell Biol 172: 875-884.

Lomvardas S, Barnea G, Pisapia DJ, Mendelsohn M, Kirkland J, Axel R. 2006. Interchromosomal interactions and olfactory receptor choice. Cell 126: 403-413.

Luco RF, Maestro MA, Sadoni N, Zink D, Ferrer J. 2008. Targeted deficiency of the transcriptional activator Hnf $1 \alpha$ alters subnuclear positioning of its genomic targets. PLoS Genet 4: e1000079.

Malhas A, Lee CF, Sanders R, Saunders NJ, Vaux DJ. 2007. Defects in lamin B1 expression or processing affect interphase chromosome position and gene expression. J Cell Biol 176: 593-603.

Mani RS, Tomlins SA, Callahan K, Ghosh A, Nyati MK, Varambally S, Palanisamy N, Chinnaiyan AM. 2009. Induced chromosomal proximity and gene fusions in prostate cancer. Science 326: 1230.

Masny PS, Bengtsson U, Chung SA, Martin JH, van Engelen B, van der Maarel SM, Winokur ST. 2004. Localization of $4 \mathrm{q} 35.2$ to the nuclear periphery: Is FSHD a nuclear envelope disease? Hum Mol Genet 13: 1857-1871.

Matarazzo MR, Boyle S, D’Esposito M, Bickmore WA. 2007. Chromosome territory reorganization in a human disease with altered DNA methylation. Proc Natl Acad Sci US A 104: 16546-16551.

Mathas S, Kreher S, Meaburn KJ, Johrens K, Lamprecht B, Assaf C, Sterry W, Kadin ME, Daibata M, Joos S, et al. 2009. Gene deregulation and spatial genome reorganization near breakpoints prior to formation of translocations in anaplastic large cell lymphoma. Proc Natl Acad Sci U S A 106: 5831-5836.
Meaburn KJ, Misteli T. 2008. Locus-specific and activity-independent gene repositioning during early tumorigenesis. J Cell Biol 180: 39-50.

Meaburn KJ, Cabuy E, Bonne G, Levy N, Morris GE, Novelli G, Kill IR, Bridger JM. 2007. Primary laminopathy fibroblasts display altered genome organization and apoptosis. Aging Cell 6: 139-153.

Meaburn KJ, Gudla PR, Khan S, Lockett SJ, Misteli T. 2009. Disease-specific gene repositioning in breast cancer. J Cell Biol 187: 801-812.

Meaburn KJ, Levy N, Toniolo D, Bridger JM. 2005. Chromosome positioning is largely unaffected in lymphoblastoid cell lines containing emerin or A-type lamin mutations. Biochem Soc Trans 33: 1438-1440.

Misteli T. 2007. Beyond the sequence: Cellular organization of genome function. Cell 128: 787-800.

Moen PTJr, Johnson CV, Byron M, Shopland LS, de la Serna IL, Imbalzano AN, Lawrence JB. 2004. Repositioning of muscle-specific genes relative to the periphery of SC-35 domains during skeletal myogenesis. Mol Biol Cell 15: 197-206.

Morey C, Kress C, Bickmore WA. 2009. Lack of bystander activation shows that localization exterior to chromosome territories is not sufficient to up-regulate gene expression. Genome Res 19: 1184-1194.

Morey C, Da Silva NR, Perry P, Bickmore WA. 2007. Nuclear reorganisation and chromatin decondensation are conserved, but distinct, mechanisms linked to Hox gene activation. Development 134: 909-919.

Murrell A, Heeson S, Reik W. 2004. Interaction between differentially methylated regions partitions the imprinted genes Igf2 and $\mathrm{H} 19$ into parent-specific chromatin loops. Nat Genet 36: 889-893.

Neves H, Ramos C, da Silva MG, Parreira A, Parreira L. 1999. The nuclear topography of ABL, BCR, PML, and RAR $\alpha$ genes: Evidence for gene proximity in specific phases of the cell cycle and stages of hematopoietic differentiation. Blood 93: 1197-1207.

Nikiforova MN, Stringer JR, Blough R, Medvedovic M, Fagin JA, Nikiforov YE. 2000. Proximity of chromosomal loci that participate in radiation-induced rearrangements in human cells. Science 290: 138-141.

Noordermeer D, Branco MR, Splinter E, Klous P, van Ijcken W, Swagemakers S, Koutsourakis M, van der Spek P, Pombo A, de Laat W. 2008. Transcription and chromatin organization of a housekeeping gene cluster containing an integrated $\beta$-globin locus control region. PLoS Genet 4: e1000016.

O'Sullivan JM, Tan-Wong SM, Morillon A, Lee B, Coles J, Mellor J, Proudfoot NJ. 2004. Gene loops juxtapose promoters and terminators in yeast. Nat Genet 36: 1014-1018.

Orlando V. 2003. Polycomb, epigenomes, and control of cell identity. Cell 112: 599-606.

Osborne CS, Chakalova L, Brown KE, Carter D, Horton A, Debrand E, Goyenechea B, Mitchell JA, Lopes S, Reik W, et al. 2004. Active genes dynamically colocalize to shared sites of ongoing transcription. Nat Genet 36: 1065-1071.

Osborne CS, Chakalova L, Mitchell JA, Horton A, Wood AL, Bolland DJ, Corcoran AE, Fraser P. 2007. Myc 


\section{Ferrai et al.}

dynamically and preferentially relocates to a transcrip tion factory occupied by Igh. PLoS Biol 5: e192.

Palstra RJ, Tolhuis B, Splinter E, Nijmeijer R, Grosveld F, de Laat W. 2003. The $\beta$-globin nuclear compartment in development and erythroid differentiation. Nat Genet 35: 190-194.

Parada L, Misteli T. 2002. Chromosome positioning in the interphase nucleus. Trends Cell Biol 12: 425-432.

Pombo A, Jackson DA, Hollinshead M, Wang Z, Roeder RG, Cook PR. 1999. Regional specialization in human nuclei: Visualization of discrete sites of transcription by RNA polymerase III. Embo J 18: 2241-2253.

Ragoczy T, Bender MA, Telling A, Byron R, Groudine M. 2006. The locus control region is required for association of the murine $\beta$-globin locus with engaged transcription factories during erythroid maturation. Genes Dev 20: 1447-1457.

Reddy KL, Zullo JM, Bertolino E, Singh H. 2008. Transcriptional repression mediated by repositioning of genes to the nuclear lamina. Nature 452: 243-247.

Rodley CD, Bertels F, Jones B, O’Sullivan JM. 2009. Global identification of yeast chromosome interactions using Genome conformation capture. Fungal Genet Biol 46: 879-886.

Roix JJ, McQueen PG, Munson PJ, Parada LA, Misteli T. 2003. Spatial proximity of translocation-prone gene loci in human lymphomas. Nat Genet 34: 287-291.

Rozycka M, Sawicki W, Traczyk Z, Bem W, Strojny P. 1988. Analysis of chromatin pattern in blood lymphocytes of healthy donors and in lymphoid cells of patients with chronic lymphocytic leukaemia. J Clin Pathol 41: 504-509.

Sabbattini P, Lundgren M, Georgiou A, Chow C, Warnes G, Dillon N. 2001. Binding of Ikaros to the lambda5 promoter silences transcription through a mechanism that does not require heterochromatin formation. Embo $J$ 20: $2812-2822$.

Sadoni N, Langer S, Fauth C, Bernardi G, Cremer T, Turner BM, Zink D. 1999. Nuclear organization of mammalian genomes. Polar chromosome territories build up functionally distinct higher order compartments. J Cell Biol 146: $1211-1226$

Sadoni N, Targosz BS, Englmann A, Fesser S, Koch J, Schindelhauer D, Zink D. 2008. Transcription-dependent spatial arrangements of CFTR and conserved adjacent loci are not conserved in human and murine nuclei. Chromosoma 117: 381-397.

Saurin AJ, Shiels C, Williamson J, Satijn DP, Otte AP, Sheer D, Freemont PS. 1998. The human polycomb group complex associates with pericentromeric heterochromatin to form a novel nuclear domain. J Cell Biol 142: 887-898.

Scaffidi P, Gordon L, Misteli T. 2005. The cell nucleus and aging: Tantalizing clues and hopeful promises. PLoS Biol 3: e395.

Schoenfelder S, Sexton T, Chakalova L, Cope NF, Horton A, Andrews S, Kurukuti S, Mitchell JA, Umlauf D, Dimitrova DS, et al. 2010. Preferential associations between co-regulated genes reveal a transcriptional interactome in erythroid cells. Nat Genet 42: 53-61.
Schuettengruber B, Chourrout D, Vervoort M, Leblanc B, Cavalli G. 2007. Genome regulation by polycomb and trithorax proteins. Cell 128: 735-745.

Schul W, van Der Kraan I, Matera AG, van Driel R, de Jong L. 1999. Nuclear domains enriched in RNA $3^{\prime}$-processing factors associate with coiled bodies and histone genes in a cell cycle-dependent manner. Mol Biol Cell 10: 3815-3824.

Sexton T, Bantignies F, Cavalli G. 2009. Genomic interactions: Chromatin loops and gene meeting points in transcriptional regulation. Semin Cell Dev Biol. 20: 849-55.

Shiels C, Islam SA, Vatcheva R, Sasieni P, Sternberg MJ, Freemont PS, Sheer D. 2001. PML bodies associate specifically with the MHC gene cluster in interphase nuclei. J Cell Sci 114: 3705-3716.

Shopland LS, Johnson CV, Lawrence JB. 2002. Evidence that all SC-35 domains contain mRNAs and that transcripts can be structurally constrained within these domains. J Struct Biol 140: 131-139.

Shopland LS, Byron M, Stein JL, Lian JB, Stein GS, Lawrence JB. 2001. Replication-dependent histone gene expression is related to Cajal body (CB) association but does not require sustained CB contact. Mol Biol Cell 12: 565-576.

Shopland LS, Johnson CV, Byron M, McNeil J, Lawrence JB. 2003. Clustering of multiple specific genes and gene-rich R-bands around SC-35 domains: Evidence for local euchromatic neighborhoods. J Cell Biol 162: 981-990.

Simonis M, Klous P, Splinter E, Moshkin Y, Willemsen R, de Wit E, van Steensel B, de Laat W. 2006. Nuclear organization of active and inactive chromatin domains uncovered by chromosome conformation capture-on-chip (4C). Nat Genet 38: 1348-1354.

Skok JA, Brown KE, Azuara V, Caparros ML, Baxter J, Takacs K, Dillon N, Gray D, Perry RP, Merkenschlager M, et al 2001. Nonequivalent nuclear location of immunoglobulin alleles in B lymphocytes. Nat Immunol 2: 848-854.

Smith KP, Lawrence JB. 2000. Interactions of U2 gene loci and their nuclear transcripts with Cajal (coiled) bodies: Evidence for PreU2 within Cajal bodies. Mol Biol Cell 11: 2987-2998.

Smith KP, Byron M, Johnson C, Xing Y, Lawrence JB. 2007. Defining early steps in mRNA transport: Mutant mRNA in myotonic dystrophy type I is blocked at entry into SC-35 domains. J Cell Biol 178: 951-964.

Smith KP, Moen PT, Wydner KL, Coleman JR, Lawrence JB. 1999. Processing of endogenous pre-mRNAs in association with SC-35 domains is gene specific. J Cell Biol 144: 617-629.

Solovei I, Kreysing M, Lanctot C, Kosem S, Peichl L, Cremer T, Guck J, Joffe B. 2009. Nuclear architecture of rod photoreceptor cells adapts to vision in mammalian evolution. Cell 137: 356-368.

Spector DL. 1993. Macromolecular domains within the cell nucleus. Annu Rev Cell Biol 9: 265-315.

Spilianakis CG, Flavell RA. 2004. Long-range intrachromosomal interactions in the $\mathrm{T}$ helper type 2 cytokine locus. Nat Immunol 5: 1017-1027.

Spilianakis CG, Lalioti MD, Town T, Lee GR, Flavell RA. 2005. Interchromosomal associations between alternatively expressed loci. Nature 435: 637-645. 
Splinter E, Heath H, Kooren J, Palstra RJ, Klous P, Grosveld F, Galjart N, de Laat W. 2006. CTCF mediates long-range chromatin looping and local histone modification in the $\beta$-globin locus. Genes Dev 20: 2349-2354.

Sproul D, Gilbert N, Bickmore WA. 2005. The role of chromatin structure in regulating the expression of clustered genes. Nat Rev Genet 6: 775-781.

Stanek D, Neugebauer KM. 2006. The Cajal body: A meeting place for spliceosomal snRNPs in the nuclear maze. Chromosoma 115: 343-354.

Sun Y, Durrin LK, Krontiris TG. 2003. Specific interaction of PML bodies with the TP53 locus in Jurkat interphase nuclei. Genomics 82: 250-252.

Szutorisz H, Dillon N, Tora L. 2005. The role of enhancers as centres for general transcription factor recruitment. Trends Biochem Sci 30: 593-599.

Takizawa T, Meaburn KJ, Misteli T. 2008b. The meaning of gene positioning. Cell 135: 9-13.

Takizawa T, Gudla PR, Guo L, Lockett S, Misteli T. 2008a. Allele-specific nuclear positioning of the monoallelically expressed astrocyte marker GFAP. Genes Dev 22: 489-498.

Tan-Wong SM, Wijayatilake HD, Proudfoot NJ. 2009. Gene loops function to maintain transcriptional memory through interaction with the nuclear pore complex. Genes Dev 23: 2610-2624.

Tiwari VK, Cope L, McGarvey KM, Ohm JE, Baylin SB 2008a. A novel 6C assay uncovers Polycomb-mediated higher order chromatin conformations. Genome Res 18: 1171-1179.

Tiwari VK, McGarvey KM, Licchesi JD, Ohm JE, Herman JG, Schubeler D, Baylin SB. 2008b. PcG proteins, DNA methylation, and gene repression by chromatin looping. PLoS Biol 6: 2911-2927.

Tolhuis B, Palstra RJ, Splinter E, Grosveld F, de Laat W. 2002. Looping and interaction between hypersensitive sites in the active $\beta$-globin locus. Mol Cell 10: 1453-1465.

Towbin BD, Meister P, Gasser SM. 2009. The nuclear envelope-a scaffold for silencing? Curr Opin Genet Dev 19: $180-186$.

Tsukamoto T, Hashiguchi N, Janicki SM, Tumbar T, Belmont AS, Spector DL. 2000. Visualization of gene activity in living cells. Nat Cell Biol 2: 871-878.

Vakoc CR, Letting DL, Gheldof N, Sawado T, Bender MA, Groudine M, Weiss MJ, Dekker J, Blobel GA. 2005. Proximity among distant regulatory elements at the $\beta$-globin locus requires GATA-1 and FOG-1. Mol Cell 17: 453-462.

Verschure PJ, van der Kraan I, Manders EM, Hoogstraten D, Houtsmuller AB, van Driel R. 2003. Condensed chromatin domains in the mammalian nucleus are accessible to large macromolecules. EMBO Rep 4: 861-866.

Verschure PJ, van Der Kraan I, Manders EM, van Driel R. 1999. Spatial relationship between transcription sites and chromosome territories. J Cell Biol 147: 13-24.

Volpi EV, Chevret E, Jones T, Vatcheva R, Williamson J, Beck S, Campbell RD, Goldsworthy M, Powis SH, Ragoussis J, et al. 2000. Large-scale chromatin organization of the major histocompatibility complex and other regions of human chromosome 6 and its response to interferon in interphase nuclei. J Cell Sci 113: 1565-1576.

Walter J, Schermelleh L, Cremer M, Tashiro S, Cremer T. 2003. Chromosome order in HeLa cells changes during mitosis and early G1, but is stably maintained during subsequent interphase stages. J Cell Biol 160: 685-697.

Wang J, Shiels C, Sasieni P, Wu PJ, Islam SA, Freemont PS, Sheer D. 2004. Promyelocytic leukemia nuclear bodies associate with transcriptionally active genomic regions. J Cell Biol 164: 515-526.

Wansink DG, Schul W, van der Kraan I, van Steensel B, van Driel R, de Jong L. 1993. Fluorescent labeling of nascent RNA reveals transcription by RNA polymerase II in domains scattered throughout the nucleus. J Cell Biol 122: $283-293$.

Webster M, Witkin KL, Cohen-Fix O. 2009. Sizing up the nucleus: Nuclear shape, size and nuclear-envelope assembly. J Cell Sci 122: 1477-1486.

Wiech T, Timme S, Riede F, Stein S, Schuricke M, Cremer C, Werner M, Hausmann M, Walch A. 2005. Human archival tissues provide a valuable source for the analysis of spatial genome organization. Histochem Cell Biol 123: 229-238.

Williams RR, Azuara V, Perry P, Sauer S, Dvorkina M, Jorgensen H, Roix J, McQueen P, Misteli T, Merkenschlager $\mathrm{M}$, et al. 2006. Neural induction promotes large-scale chromatin reorganisation of the Mash1 locus. J Cell Sci 119: $132-140$

Xie SQ, Martin S, Guillot PV, Bentley DL, Pombo A. 2006. Splicing speckles are not reservoirs of RNA polymerase II, but contain an inactive form, phosphorylated on serine2 residues of the C-terminal domain. Mol Biol Cell 17: $1723-1733$.

Xing Y, Johnson CV, Moen PTJr, McNeil JA, Lawrence J. 1995. Nonrandom gene organization: Structural arrangements of specific pre-mRNA transcription and splicing with SC-35 domains. J Cell Biol 131: 1635-1647.

Xu M, Cook PR. 2008. Similar active genes cluster in specialized transcription factories. J Cell Biol 181: 615-623.

Xu N, Tsai CL, Lee JT. 2006. Transient homologous chromosome pairing marks the onset of $\mathrm{X}$ inactivation. Science 311: 1149-1152.

Zhao Z, Tavoosidana G, Sjolinder M, Gondor A, Mariano P, Wang S, Kanduri C, Lezcano M, Sandhu KS, Singh U, et al. 2006. Circular chromosome conformation capture (4C) uncovers extensive networks of epigenetically regulated intra- and interchromosomal interactions. Nat Genet 38: 1341-1347.

Zink D, Amaral MD, Englmann A, Lang S, Clarke LA, Rudolph C, Alt F, Luther K, Braz C, Sadoni N, et al. 2004. Transcription-dependent spatial arrangements of CFTR and adjacent genes in human cell nuclei. J Cell Biol 166: 815-825. 


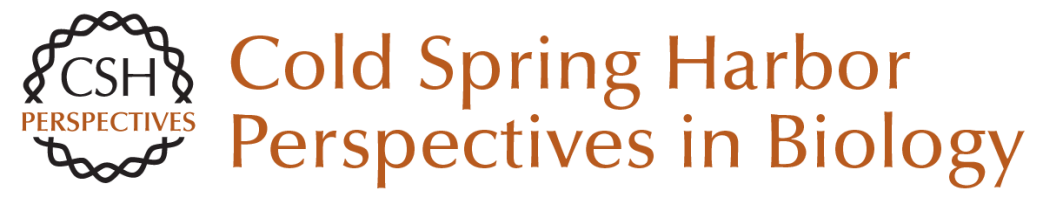

\section{Gene Positioning}

Carmelo Ferrai, Inês Jesus de Castro, Liron Lavitas, Mita Chotalia and Ana Pombo

Cold Spring Harb Perspect Biol 2010; doi: 10.1101/cshperspect.a000588 originally published online May 19,2010

\section{Subject Collection The Nucleus}

Nuclear Compartments: An Incomplete Primer to Nuclear Compartments, Bodies, and Genome Organization Relative to Nuclear Architecture Andrew S. Belmont

Uncovering the Principles of Genome Folding by 3D Chromatin Modeling

Asli Yildirim, Lorenzo Boninsegna, Yuxiang Zhan, et al.

3D or Not 3D: Shaping the Genome during Development Juliane Glaser and Stefan Mundlos

The Impact of Space and Time on the Functional Output of the Genome Marcelo Nollmann, Isma Bennabi, Markus Götz, et al.

\section{Chromatin Mechanisms Driving Cancer}

Berkley Gryder, Peter C. Scacheri, Thomas Ried, et al.

\section{Liquid-Liquid Phase Separation in Chromatin Karsten Rippe}

Mechanical Forces in Nuclear Organization Yekaterina A. Miroshnikova and Sara A. Wickström

Imaging Organization of RNA Processing within the Nucleus

Jeetayu Biswas, Weihan Li, Robert H. Singer, et al.
Mechanisms of Chromosome Folding and Nuclear Organization: Their Interplay and Open Questions Leonid Mirny and Job Dekker

Epigenetic Reprogramming in Early Animal Development

Zhenhai Du, Ke Zhang and Wei Xie

\section{Essential Roles for RNA in Shaping Nuclear} Organization

Sofia A. Quinodoz and Mitchell Guttman

The Molecular and Nuclear Dynamics of

$\mathrm{X}$-Chromosome Inactivation

François Dossin and Edith Heard

Structure, Maintenance, and Regulation of

Nuclear Pore Complexes: The Gatekeepers of the

Eukaryotic Genome Marcela Raices and Maximiliano A. D'Angelo

The Nuclear Lamina Xianrong Wong, Ashley J. Melendez-Perez and Karen L. Reddy

The Nuclear Pore Complex as a Transcription Regulator Michael Chas Sumner and Jason Brickner

Physical Nature of Chromatin in the Nucleus Kazuhiro Maeshima, Shiori lida and Sachiko Tamura

For additional articles in this collection, see http://cshperspectives.cshlp.org/cgi/collection/

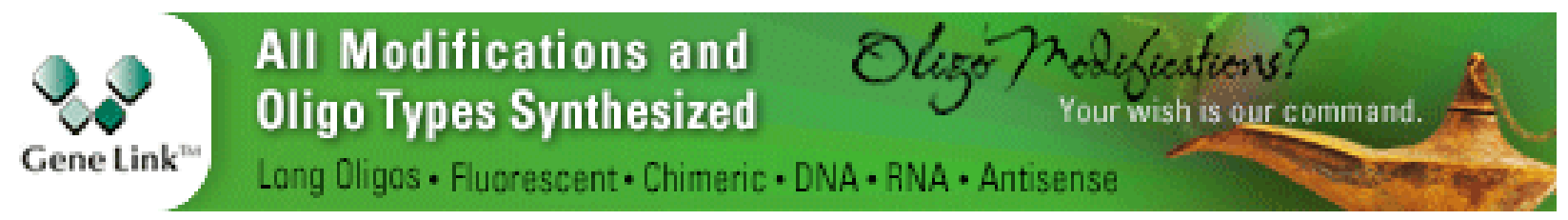


For additional articles in this collection, see http://cshperspectives.cshlp.org/cgi/collection/

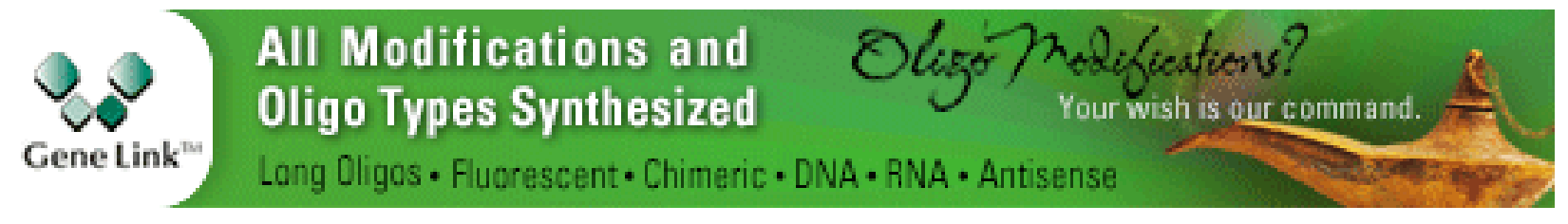

Copyright @ 2010 Cold Spring Harbor Laboratory Press; all rights reserved 